\title{
The Problems of Developing School-Enterprise Cooperation in Vocational Education Under the Background of Deepening the Integration of Industry and Education
}

\author{
Mingyu Zhang ${ }^{1}$, Ya Wang ${ }^{2, *}$ \\ ${ }^{1}$ Suzhou Vocational Institute of Industrial Technology, Suzhou 215104, China; \\ ${ }^{2}$ Shanghai Urban Construction Vocational College, Shanghai 201415, China \\ *Corresponding author. Email: zmy_hlg@163.com
}

\begin{abstract}
This article explains the current situation of school-enterprise cooperation in China's higher vocational education, and analyzes the reasons for the low quality of talent training in school-enterprise cooperation. The main reasons include: the lack of enthusiasm between the school and the enterprise, the insufficient understanding of high vocational colleges in the in-depth school-enterprise cooperation, the mechanism of school-enterprise cooperation still needs to be improved, and teachers' practice and scientific research capabilities need to be improved. Deepening the integration of production and education and accelerating school-enterprise cooperation is the only way for the development and reform of higher vocational colleges, and it is also one of the difficulties encountered in the development of higher vocational colleges. School-enterprise cooperation distinguishes higher vocational education from ordinary higher education. The core characteristics of vocational education are also an important way for the development of higher vocational education. At present, many higher vocational colleges are vigorously developing school-enterprise cooperation. While the schoolenterprise cooperation has achieved results, there are also certain problems. This article analyzes the current situation of school-enterprise cooperation in higher vocational education, and points out the problems and causes of schoolenterprise cooperation, which lays the foundation for the next step of research on related countermeasures.
\end{abstract}

Keywords: higher vocational education, integration of production and education, school enterprise cooperation

\section{INTRODUCTION}

Since the beginning of the new century, China's education has developed vigorously and provided a large number of high-quality talents for society, and has made significant contributions to accelerating the development and growth of the modern industrial system. But at the same time, affected by various factors such as the mechanism of the society and goverment, the training of talents and the demanding of the industry cannot fully match with each other in terms of structure, quality, and level. The problem of "two skins" still exists. Deepening the integration of production and education, and promoting the organic connection between the education chain, the talent chain, the industrial chain, and the innovation chain are the current urgent requirements for advancing the structural reform of the human resources supplying, and is of great significance in comprehensively improving the quality of education, expanding employment and entrepreneurship, promoting economic transformation under the new situation, and upgrading and fostering new drivers of economic development. However, China's vocational education still has many problems, such as the system of vocational education construction still need to be improved; vocational skills training base construction needs to be strengthened; system standards is insufficient; the motivation for enterprises to participate in running schools is insufficient; supporting policies that are conducive to the growth of technical skills and talents need to be perfected, and the capabilities of school running and talents training are uneven, etc. It's time that we must make great efforts to do it well. Without the modernization of vocational education, there will be no 
modernization of education. Only by further deepening the integration of production and education and promoting the organic connection of the education chain, the talent chain, the industrial chain, and the innovation chain, can the school-enterprise collaborative education be fully implemented. How to deepen the integration of production and education, build a long-term mechanism for school-enterprise cooperation, carry out collaborative innovation around key industrial technologies, core processes and common issues, and accelerate the transformation of research results into industrial technology are the bottleneck problems faced by the higher vocational colleges. With the continuous development of higher vocational colleges, schoolenterprise cooperation, as an important form of higher vocational education, plays an irreplaceable role in improving the quality of vocational education and promoting the sustainable development of vocational education. Many breakthrough, characteristic and effective vocational education school-enterprise cooperation models and practices continue to emerge, and higher vocational education school-enterprise cooperation has shown a good development situation. Therefore, higher vocational colleges must insist on deepening the integration of production and education and school-enterprise cooperation, making it as the source of school development and innovation. At the same time, it is necessary to mobilize the enthusiasm of enterprises to participate in school-enterprise cooperation and enhance the attractiveness of higher vocational education.

\section{THE SITUATION OF HIGHER VOCATIONAL SCHOOL-ENTERPRISE COOPERATION}

Since its inception, higher vocational education has differentiated its training ideas from ordinary colleges and universities, focusing on production-education cooperation to cultivate high-quality application-oriented talents, and taking this as the core task. The talent training process reflects the characteristics of vocational education, including: talent training plan is flexibly adapted to the needs of the enterprise, especially in the curriculum setting that focuses on the connection with the skills required by the job requirement; the teachers have "dual-professional" quality with rich practical experience; the joint education of production-education collaboration is emphasized, and the company must participate in talent training process. The "dual system" model has a certain foundation in Europe. Among them, Germany's vocational education is a typical representative, which has accumulated for a long term and accompanied by industrial development. It originated from the apprenticeship system of the handicraft industry in the Middle Ages. It emphasizes the joint training of enterprises and schools in the process of talent training, in which the enterprises play a leading role, and schools are mainly assistant. Students spend more time on practical learning in corporate positions, and time spent in school learning is relatively short, with a time ratio of $3: 2$ or $4: 1$. The Germany's "dual system" is a model of school-enterprise cooperation in educating talents, and has cultivated a large number of high-quality skilled talents for Germany. Australia's vocational education model is different from other countries. As an important part of the national education, it is not juxtaposed with undergraduate and junior college education, but has been developed as a lifelong vocational education system that can effectively integrate academic and non-academic education. Compared with Germany's "dual system", it takes the school as the leading part, and enterprises as the supplement". However, as an important supplier of social labor, the vocational school still have to work closely with enterprises to achieve the goal of improving the students' professional competence, by corporate practice or social practice, so that the trainees' abilities are closer to the needs of the enterprise, and the contradiction between supply and demand of high-quality labor can be solved. The "teaching factory" model draws on the Germany's "dual system", but in comparison it is weaker than the latter in emphasizing the dominant position of the enterprise. This model emphasizes the cultivation of students' professional ability, whether it is by moving the real environment of the enterprise to the campus, or by building an advanced training center in the school, they are all teaching activities with the purpose of building a professional situation and supporting the enterprise's real projects. Teachers are mainly instructive, and it is more important that the students take the initiative in learning and training to improve their skills, so that the three-inone comprehensive professional training model of school, enterprise and training center can be realized. Some scholars concluded that China's school-enterprise cooperation model can be summarized into mainly two types. One is a loose cooperation model, which is centered on cooperative education. Although both schools and enterprises jointly set up experimental training centers and share resources and equipment, the training and guidance of students is still dominated by schools, and the companies rarely participate; the other type is close cooperation mode, which is a trinity cooperation of teaching, production, and scientific research. Both schools and enterprises cooperate closely to build experimental training centers, jointly develop teaching materials, jointly conduct technological research and development, and share scientific and technological achievements. Under this model, both schools and enterprises have extended talent training modes such as "order education", "internship", "workstudy alternation", "school-enterprise integration" and "joint research and development". Therefore, the close cooperation mode is consistent with China's national conditions, and is currently the best model for development and implementation of school-enterprise cooperation [1-8]. 


\section{ANALYSIS ON THE PROBLEMS AND CAUSES OF THE COOPERATION BETWEEN SCHOOL AND ENTERPRISE IN HIGHER VOCATIONAL EDUCATION}

\subsection{There is a phenomenon of low enthusiasm for cooperation between schools and enterprises}

Both parties of school-enterprise cooperation have concerns, situation in which one party is eager to cooperate with the other party, while the other party's enthusiasm is insufficient, even some of them simply response to the cooperation as it arise. The school has sufficient motivation to cooperate in order to increase the employment rate of students, but the enterprises have insufficient motivation because their interests are not met. School-enterprise cooperation should be based on complementary advantages and win-win cooperation. If one party's interests are damaged, this kind of cooperative relationship will inevitably be difficult to maintain. Deeply digging out the motivation of enterprises to participate in school-enterprise cooperation and the obstacles that restrict their enthusiasm, so that the government can formulate relevant supportive policies in a targeted manner is the key to solving the current schoolenterprise cooperation problems in China. The reason for this phenomenon is that first, higher vocational colleges take the training of students and ensuring their safety as the starting point, and they are concerned about the problems that may arise in enterprises for students. Second, enterprises do not have a high degree of understanding of school-enterprise cooperation and believe that talent training is a matter of schools, and it is enough for them to directly recruit employees who can take the job, so there is obviously a problem of insufficient motivation in participating in schoolenterprise cooperation. Third, higher vocational colleges cannot satisfy the interests of enterprises. With the purpose of pursuing economic benefits, enterprises participating in school-enterprise cooperation in higher vocational colleges must not only provide human, financial and material resources, but also provide related services. These are not good for improving the economic efficiency of enterprises. Even if some companies have the intention to cooperate, they mostly pursue short-term benefits without long-term goals. This has a great impact on the enthusiasm of companies to participate in schoolenterprise cooperation.

\subsection{Insufficient understanding of the in-depth cooperation between schools and enterprises}

The school-enterprise cooperation model is an important way to cultivate technical application-oriented talents. It has been widely promoted in higher vocational colleges. The main forms of school-enterprise cooperation are shown in Table I. As can be seen from the table, the school-enterprise cooperation is present with various forms, including both internal and external introduction practice in schools, and internal introduction and retraining by enterprises. However, as far as the current situation is concerned, there is still a general lack of understanding of the importance of school-enterprise cooperation in higher vocational colleges. The school only moves a certain process or equipment in the production of the enterprise into the school, and then the teacher teaches and demonstrates relevant knowledge; or the enterprise sends relevant technical personnel to the school to promote the corporate culture, treatment, connotation, etc., in order to provide students with employment position. Even if the school and the enterprise have established a long-term or short-term cooperative relationship, due to the different interests, systems, and models of the school and enterprise, the traditional school-enterprise cooperation has insufficient timeliness and effectiveness, and is far from meeting the needs of talent training. It is mainly manifested in the inadequate understanding of the deep connotation of school-enterprise cooperation. Many higher vocational colleges simply think that school-enterprise cooperation means that the school introduces enterprises in to the campus, or introduces students to enterprises. While the most fundamental purpose of school-enterprise cooperation lies in cultivating first-class applicationskilled talents in practice; some higher vocational colleges introduce students to enterprises for fixed-post internships, but seldom really get to the deeper level of what the positions actually need. There are also some vocational colleges who superficially believe that schoolenterprise cooperation means keeping up with the pace of policy and putting a lot of effort into superficial writing, instead of unfolding the most substantial and important talent training tasks in school-enterprise cooperation. The first reason for these phenomena is the imperfect faculty and curriculum system of higher vocational colleges. Some young teachers enter colleges directly after graduating from universities and lack practical experience in enterprises. Second, the teaching mode is still mainly based on lectures, which has not achieved the true integration of school-enterprise cooperation. Third, the training conditions in the school cannot reach the actual level of real factory production. Some higher vocational colleges lack practical training equipment corresponding to school-enterprise cooperation, and the level of practical training cannot meet the actual requirements of school-enterprise cooperation. Fourth, vocational colleges do not pay enough attention to scientific research, and the scientific research environment of a considerable part of vocational colleges does not meet the needs of in-depth cooperation between schools and enterprises, and the problem of insufficient technological innovation extended from this obviously cannot meet the innovation needs of enterprises. 
Table 1. School-enterprise cooperation form

\begin{tabular}{|c|c|}
\hline Form of cooperation & Method to realize \\
\hline Order naming class training & $\begin{array}{c}\text { Order naming class } \\
\text { training }\end{array}$ \\
\hline Internships & Internships \\
\hline Enterprise class teacher & Enterprise class teacher \\
\hline Development Course & Development Course \\
\hline Enterprise Teacher & $\begin{array}{c}\text { Enterprise Teacher } \\
\text { Workstation }\end{array}$ \\
\hline Enterprise part-time teacher & $\begin{array}{c}\text { Enterprise part-time } \\
\text { teacher }\end{array}$ \\
\hline $\begin{array}{c}\text { Enterprise employees to } \\
\text { school training }\end{array}$ & $\begin{array}{c}\text { Enterprise employees } \\
\text { to school training }\end{array}$ \\
\hline
\end{tabular}

\subsection{The school-enterprise cooperation mechanism needs to be improved}

First, in the process of promoting school-enterprise cooperation, the government has not formed very sound policies and regulations that protect and actively guide school-enterprise cooperation. Although some schoolenterprise cooperation policies have been introduced, such as tax incentives for enterprises, in actual operation, tax incentives have not been fully implemented. Second, higher vocational colleges have not formed an effective education model mechanism for cooperation with enterprises, which to a large extent restricts the continuous and effective development of schoolenterprise cooperation. Companies hope that they can obtain "finished graduates" who can directly take up their jobs from higher vocational colleges, and do not want to spend too much time and money for the pre-job training stage. At the same time, as the degree of refinement of the occupational division of labor in enterprises continues to deepen, the demand for "more capable, occupational and professional" talents has increased, and this has put forward higher requirements on the curriculum and training of highly skilled personnel for the higher vocational colleges. For a long time, the teaching of many domestic higher vocational colleges is generally divorced from industry reality, and the phenomenon of emphasizing theory and neglecting practice appears. This is obviously contrary to the purpose of vocational colleges, and is not conducive to the improvement of students' practical ability, and do not meet the rule of talent development should be based on the adjustment of industrial structure. Although the state has formulated corresponding guidelines and principles for schoolenterprise cooperation and the combination of work and study, there is a lack of specific and operable policies, regulations and implementation rules, and the responsibilities, rights and benefits of the schoolenterprise cooperation are not defined clearly. In the traditional school-enterprise cooperation, the school is only responsible for the organization, management, and engineering process planning of students. When encountering problems and difficulties, it does not communicate with the company in time and effectively solve the problems, which lead to some incidents and resistant of students. Meanwhile, enterprises have problems such as unsound mechanisms, unclear responsibilities and powers, and lack the binding force and driving force to participate in vocational education.

\subsection{Teachers' practical and scientific research capabilities need to be improved}

For schools, teachers and students are the main body, and the quality of student training reflects the strength of the school, and what this needs most is the professional quality of teachers. However, the practice and scientific research capabilities of teachers are still insufficient. The main reason is that the majority of teachers do not have a good practice platform, and they have not actively sought business cooperation. Schools and enterprises have not provided teachers with opportunities to practice on the front line of enterprises or production. Teachers have not taken the initiative to go out of the school to industry or enterprises to help solve problems. The service system that aims to improve teachers' professional quality has not been opened up, and the bridge between teachers and enterprises has not been established. Vocational colleges in the new era need scientific research and innovation to lead development, and the teachers need to explore the laws of modern vocational education, and solve the hot and difficult problems of vocational education reform. They should closely cooperate with enterprises to develop urgently needed application technologies, and lead talents training with excellent educational and technological research results. College leaders, teachers, and administrators should attach great importance to scientific research and innovation, consider from the perspective of the strategic development of the school, and enhance the sense of urgency and responsibility to carry out scientific research innovation

\section{CONCLUSIONS}

Deepening the integration of production and education and accelerating school-enterprise cooperation is the only way for the development and reform of higher vocational colleges, and it is also one of the difficulties encountered in the development of higher vocational colleges. School-enterprise cooperation distinguishes higher vocational education from ordinary higher education, and it is also an important way for the development of higher vocational education. At present, many higher vocational colleges are vigorously developing school-enterprise cooperation. While the school-enterprise cooperation has achieved results, there are also certain problems. This article analyzes the current situation of school-enterprise cooperation in 
higher vocational education, and points out the problems and causes of school-enterprise cooperation, which lays the foundation for the next step of research on related countermeasures.

\section{ACKNOWLEDGMENTS}

This work was financially supported by the Social Science Research in Colleges and Universities inJiangsu Province (2019SJA1375).

\section{REFERENCES}

[1] Li P. (2019) The Difficulties and Countermeasures of Internal Management in Higher Vocational Colleges under the Background of "Streamlining Administration, Delegating Powers, Improving Regulations and Optimizing Services"[J]. Continue Education Research, 163: 51-59.

[2] Hui C. (2019) Difficulties and Countermeasures of E-commerce Development in Commerce and Circulation Enterprises Under the Background of "One Belt and One Road"[J]. Journal of Jiangsu University of Technology, 66:5-10.

[3] Li-Qin, Xiao-Dan Z . (2016) On the bottleneck problems and countermeasures of school-enterprise cooperation in higher vocational colleges of accounting $[\mathrm{J}]$. Journal of Hubei Industrial Polytechnic, 5:10-16.

[4] Jian-Ning T. (2017) Research on the countermeasures and mechanism innovation of the problem of talent flow in private applied technology[J]. Journal of Jiamusi Vocational Institute, 1:20-25.

[5] Ai-Zhen R. (2016) On Working Process-oriented Curriculum Development of School-enterprise Cooperation in Higher Vocational Colleges[J]. Research on Modern Vocational Education, 3:5-9.

[6] Ji Y, Yi L I, Yihui D U, et al. (2015) Role in Promoting Professional Development of Schoolenterprise Cooperation in Vocational Architectural Design Technology_-Take Chongqing Real Estate College as an example[J]. The Guide of Science \& Education, 5:30-35.

[7] Aizhen R, Zhuping T , Xuefeng L . (2017) Enlightenment of Chuang-tzu Thought on the Development of School Enterprise Cooperation in Higher Vocational Colleges_Electronic Information Technology Curriculum as an Example[J]. Journal of Ningbo Polytechnic, 6:16-21.

[8] Haisheng P, Shibin W, Deyi L . (2013) Analysis of the Current State of School-Enterprise Cooperation in Chinese Higher Vocational Education and
Influencing Factors[J]. Research in Higher Education of Engineering, 49(3):152-165 